Bond University ePublications@bond

Sports Law eJournal

Faculty of Law

9-7-2007

\title{
The use of criminal justice mechanisms to combat doping in sport
}

Christopher McKenzie

Follow this and additional works at: http://epublications.bond.edu.au/slej

Part of the Entertainment, Arts, and Sports Law Commons

\section{Recommended Citation}

Christopher McKenzie. (2007) "The use of criminal justice mechanisms to combat doping in sport" $\mu$.

http://epublications.bond.edu.au/slej/4 


\title{
The use of criminal justice mechanisms to combat doping in sport
}

\begin{abstract}
Drugs cheats in professional cycling, as well as in other sports, may be liable to criminal justice sanction under current law. Adopting criminal justice mechanisms and being firm in denunciation of dishonest conduct in sport through the use of criminal charges against athletes and sports managers may challenge doping more effectively than is achievable through administrative sanction and education.
\end{abstract}

\section{Disciplines}

Entertainment, Arts, and Sports Law 


\title{
The use of criminal justice mechanisms to combat doping in sport
}

\author{
By Christopher McKenzie \\ Barrister, Brisbane
}

Published 31 August 2007

Drugs cheats in professional cycling, as well as in other sports, may be liable to criminal justice sanction under current law. Adopting criminal justice mechanisms and being firm in denunciation of dishonest conduct in sport through the use of criminal charges against athletes and sports managers may challenge doping more effectively than is achievable through administrative sanction and education.

Recent doping scandals in professional cycling - including (i) the positive drug test and United States Anti Doping Agency (USADA) hearing of the putative winner of the 2006 Tour de France, Floyd Landis; (ii) the Operación Puerto investigation by Spanish police into the behaviour of scores of professional cyclists including notables such as Ivan Basso, Jan Ullrich and Francisco Mancebo; (iii) the positive drug test of Alexander Vinokurov in the 2007 Tour, prompting the withdrawal of the Astana team from the race; and (iv) the expulsion of Tour leader Michael Rasmussen from the 2007 race for missing drug testing in May and June 2007 and lying about his whereabouts highlight the failure of the existing administrative anti-doping system operated by many national governments. The use of criminal justice mechanisms by Spanish and Italian governments in particular - such as the use of police investigative expertise, formal police interviews, prosecutions and trials against professional cyclists, trainers, doctors, and directors of cycling teams - has resulted in a purge of doping in cycling which several years of anti-doping administration and education failed to uncover.

\section{Two anti doping systems}

Both common law and civil law legal systems are investigating doping in cycling, but are handling it in different ways. On one hand, the Spanish, Italian, and Belgian governments, and the French government formerly, are involved in public law criminal justice investigations. On the other hand, in countries such as the United States and Australia, inquiries into doping in sport are conducted as a matter of private law between the sportsperson and the administrators of his sport before an administrative agency, such as the 
USADA, or a private arbitration panel, such as the Court of Arbitration for Sport (CAS). Floyd Landis has contested the imposition of an administrative ban by the international cycling federation (UCI) and the cycling federation of the United States, which would prevent him from eligibility to compete in any competition run by those federations.

The two systems approach the problem of quelling doping in sport from divergent perspectives. The use of criminal justice mechanisms has uncovered not only culpability on the part of individual athletes, but also a culture of fraud within professional cycling teams who strive to maximize commerciality above sportsmanship. Administrative processes are designed only to block infringing athletes from competing in races for intermittent periods. A number of riders have competed in Tour de France races after serving bans from cycling, including, for example, the Festina trio of Alex Zulle, Armin Meier and Laurent Dufaux, who were given eight-month bans by the UCI after their admissions to police in interviews in July 1998 of using performance-enhancing drugs. All three riders were allowed to compete in the 1999 Tour de France. Administrative processes are self-serving and of limited effectiveness. The success of the differing systems in combating doping in cycling is marked.

\section{Criminal justice mechanisms}

The Spanish police investigation Operación Puerto, the Belgian police investigation of the Quick Step professional cycling team in June 2007, the Bocciolini investigation of cyclists and teams competing in the 2001 Giro d'Italia, and the investigation by French police into the Festina cycling team in July 1998, are examples of the use of formal police investigations, formal police interviews, formal charges, court processes, trials, acquittals, findings of culpability, sentences, fines, and custodial imprisonment.

Operación Puerto was launched in late 2005, in response to the Spanish government's commitment to weed out doping in sport. The investigation by the Guardia Civil in Madrid implicates 107 riders who had association with the manager of the Liberty-Seguros cycling team, Manolo Saiz, one of the most esteemed and experienced directeur sportifs in cycling, and Spanish doctors Eufemiano Fuentes and Jose Luis who were arrested on 23 May 2006. Police raids at a number of different places revealed large quantities of medical supplies, anabolic steroids, and more than 200 frozen packs of blood.

On 7 June 2007, Belgian police raided the homes of cyclists, assistants and soigneurs of the Quick Step professional cycling team and seized a large 
quantity of prohibited doping substances. 13 persons were taken into police custody for questioning. ${ }^{1}$

2001 saw an investigation into doping in cycling in Italy, after some 200 police raided team hotels in San Remo during the Giro d'Italia race. Human growth hormones, insulin, cortisone-based products and drug paraphernalia were seized in the search. 34 cyclists, team doctors and trainers were charged with sporting fraud under Italian law. Several received suspended sentences, actual custodial imprisonment, and fines upon conviction after court trials in 2004 and 2005.

A judge in a San Remo court found five Italian riders and a masseur guilty on 24 October 2005 of doping offences during the 2001 Giro d'Italia. Giuseppe Di Grande, Alberto Elli and Dario Frigo were handed 6-month suspended sentences and fines of $€ 4,000$. Former riders Domenico Romano and Ermanno Brignoli received sentences of 5 months 20 days and 1 month 10 days imprisonment respectively, being the number of days they had spent in custody pending trial. Primo Pregnolato, who at the time worked as the personal masseur to Marco Pantani, received an 8-month suspended sentence and a $€ 6,000$ fine. The riders Giuliano Figueras, Pavel Padrnos, Stefano Zanini, Giampaolo Mondini and Daniele De Paoli were cleared of charges by the court.

1998 saw an investigation by French police into the Festina cycling team, resulting in a number of arrests. The Festina team were caught by French customs officials with 250 batches of anabolic steroids and some 400 ampoules of the banned growth hormone EPO in the boot of the team car. The team's director, doctor and masseur were all charged under French law, each receiving suspended-sentences and fines upon conviction at trial in 2000.

The criminality with which the French prosecutorial authorities were concerned was the trafficking of drugs, not the cheating or fraudulent activity of the cyclists themselves. At the conclusion of the trial on the charges, on 22 December 2000 in Lille, France, Voet was given a 10-month suspended sentence and a 30,000 francs fine. The court imposed a one-year suspended sentence with a fine of 50,000 francs on Roussel.

Richard Virenque, at the time one of the highest paid riders on the European cycling circuit, and the runner-up in the 1997 Tour, was charged on 31 March 1999 with conspiracy to use, and facilitate the use of, doping products under

$1<$ http://www.cnn.com/2007/SPORT/06/07/cycling.doping/index.html?section=cnn_latest $>$ at 14 June 2007. 
France's 1989 Anti-doping Act. He faced trial in Lille, France, on 25 October 2000. Virenque continuously denied any involvement in doping from the time of his first being implicated in the scandal in July 1998 until his trial. At his trial he finally admitted that he had taken performance-enhancing drugs. He tearfully admitted in the courtroom to using drugs to improve his performance in the Tour de France races. On 22 December 2000 he was cleared of actively organizing doping in his Festina team during the 1998 Tour, despite his admission of personal use of performance-enhancing drugs.

Eric Ryckaert, the Festina cycling team doctor, went on trial for breaching Belgium's drug laws and was fined 600,000 Belgian francs by a court in Ghent on 2 October 2000. The public prosecutor had asked for a 6 month jail sentence, but this was denied by the court. Dr Ryckaert was sentenced for his part in trafficking the red-blood cell boosting drug EPO. He supplied between 100 and 120 phials per year for Festina, as well as about 70 doses of growth hormones.

Cees Priem, the sporting director of the Dutch cycling team TVM during the 1998 Tour de France, was found to be the principal organizer of doping within the TVM team at trial in Reims in July 2001. He received an 18 month suspended sentence and a fine of 80,000 French francs. Mikhailov, the TVM team doctor who supervised the doping, received a one-year sentence and a 60,000 francs fine. And Ian Moors, the team physiotherapist, received a sixmonth sentence and a 10,000 francs fine.

\section{The use of administrative processes}

Floyd Landis, the putative winner of the 2006 Tour de France, tested positive for synthetic testosterone in both an ' $A$ ' and 'B' blood sample taken from him on the day he thrillingly won by more than 5 minutes over his fellow riders on the mountains of the French Alps on stage 17 of the Tour. An arbitration hearing before the United States Anti-Doping Agency (USADA) to determine the imposition of an administrative ban on Landis' eligibility to compete concluded on 23 May 2007 after nine days. Upon appeal from either side, the case will move to the CAS, a process that may take up to a year.

2003 and 2004 saw an inquiry into the activities of the Australian Cycling team in the months before the Olympic Games in Athens. Drug syringes, equine growth hormone, glucocorticosteroid, and drug paraphernalia were discovered in a rubbish bin in the room occupied by Mark French, a promising young cyclist, at the Australian Institute of Sport (AIS) cycling training facility in Adelaide. Cycling Australia, the administrative body 
governing cycling in Australia, sought to impose an administrative ban from

cycling on French. French appealed to CAS arbitrators. The arbitrators found that French had not committed a doping offence because it could not be established by the evidence that he had used performance-enhancing drugs. The panel opined that, 'because of cross-contamination arising from the manner of storage [of the syringe containing equine growth hormone], [and] the insecure and undocumented continuity (of the handling of the evidence)', the evidence was insufficient to conclude that French had breached Cycling Australia's anti doping policy. This was so despite the fact that drugs and drug paraphernalia were found in his possession.

\section{The problem of doping}

Underlying the doping scandals that have affected the Tour de France, specifically, and professional cycling, more generally, in recent years, is cupidity; greed for glory; greed for sponsorship; greed for financial gain. As evidenced by the Festina investigation, Operación Puerto, the Belgian police investigation into the Quick Step team and the Team Telekom voluntary admissions to systematic doping aired on German television, there exists a willingness on the part of professional cycling teams to pursue commerciality above traditional sportsmanship principles. Cyclists who use performanceenhancing drugs are motivated by greed to obtain advantages against their fellow competitors, against race organizers, and against the governing administrators of their sport who provide them with professional licenses. With the exception of the Italian judicial processes against cheating cyclists which have seen a number of cyclists given prison sentences under Italian law - many governmental authorities refrain from vilifying cyclists and sports managers individually.

\section{Governmental responses to doping in cycling}

Governments have responded to the doping scandals in cycling either by recommitting to administrative processes and strengthening the powers of administrative agencies in fighting doping, or by promulgating new sports fraud laws and adopting criminal justice mechanisms to purge the sport of criminality.

\section{Stronger administrative powers}

Following the doping scandals in France in 1998 and in Australia in 2003-4, the governments of both countries have promulgated legislation in an endeavour to battle the persistent problem of doping in sport. 
In Australia, the government established the Australian Sports Anti-Doping Authority (ASADA) pursuant to the Australian Sports Anti-Doping Authority Act 2006 (Cth). ASADA has been created so that a government authority is now responsible for conducting investigations into doping allegations in sport, rather than leaving it to each sports federation to investigate allegations. The authority provides national doping control (testing) and education programs; has power to establish anti-doping rules; investigates breaches of the anti-doping rules; and presents the findings of analyses at administrative hearings against athletes subject to doping allegations.

What ASADA is not is a police or prosecutorial authority. ASADA's powers are limited. The primary objective for ASADA, pursuant to s 21 of the Act, is to protect the business reputation of sports organizations from being damaged by the use of drugs in sport. The ASADA legislation does not create formal doping offences for which an athlete can be charged and tried in a court of law. The possession of drugs or doping paraphernalia at a governmentfunded sporting facility, such as the AIS, is not made an offence punishable by imprisonment. Nor is an offence of sporting fraud created for the use of performance-enhancing drugs in order to obtain or maintain a sports scholarship, or some other benefit, from the government. The only penalty which can be imposed upon offenders remains an administrative ban from competing in the sport in which the doping infraction occurred. A hearing into any breaches of anti-doping rules is conducted either in-house, within a sport's federation itself, or in arbitration before CAS lawyers. There is no independent transparent judicial process. The process remains a matter of private law between the individual parties to the dispute.

The response of the French government to the doping scandals in cycling was different to the response of the Australian government. France has adopted a middle path, strengthening their administrative processes whilst also criminalizing some conduct connected with doping in sport. New legislation in April 2006 created more strident penalties for infractors of France's antidoping policy. Under the Code $d u$ Sport, it is an offence not only to use substances or processes likely to modify ability in an athlete artificially, but also to prescribe illicit substances to an athlete, or to facilitate or encourage the use of an illicit drug by an athlete (articles 232-9 and 232-10). Supplying a prohibited substance to an athlete results not only in an administrative sanction to be imposed by a national sports organization (pursuant to article 232-21), but is now also a criminal act punishable by 5 years imprisonment and a $€ 75,000$ fine (article 232-26). Athletes, however, remain free from penal sanction under the Code, being liable only to administrative sanction by the national sports organization, although they can be punished by 6 months imprisonment and a fine of $€ 7,500$ for refusing to comply with a lawful 
doping test or for failing to abide by an administrative sanction imposed by the French anti-doping agency (article 232-25).

\section{Adopting criminal justice mechanisms}

The new regimes existing in Australia and in France, whereby government agencies conduct tests on athletes and investigate breaches of the anti-doping policy, is in stark contrast to the old regime where sports investigated themselves. They are also in stark contrast to the processes employed recently in Italy, and now in Spain.

Italy has adopted the most strident means to combat doping in sport. The Disciplina della tutela sanitaria delle attivita' sportive e della lotta contro il doping, Law number 376 of 2000, provides, in article 9, for the imprisonment of any athlete using banned substances for a period of three months to three years and a fine of 5 million to 10 million lire $(€ 2,500-€ 5,000)$. For any person, including any doctor, athlete, manager, or attendant to a sports team, supplying drugs to athletes the Act imposes imprisonment for 2 to 6 years and a fine of 10 million to 150 million lire $(€ 5,000-€ 75,000)$. The Act also allows judges to impose permanent sanction from employment with a sports organization. This is the law under which sentences have been imposed on several professional cyclists in Italian courts over recent years.

\section{The use of criminal justice processes in combating doping in Australian jurisdictions}

The limitations of the ASADA Act in Australia and of the Code du Sport in France do not preclude the use of criminal justice mechanisms.

Each Australian State has criminal law statutes which provide that certain defined acts are unlawful and punishable by imprisonment. France has the same. In lieu of new offences with which to charge athletes possessing performance-enhancing drugs, or drug paraphernalia, such as now exists in Italy, the offence which most closely reflects the conduct of athletes taking drugs, as well as doctors, managers, or attendants supplying or facilitating the use of performance-enhancing drugs, is the offence of fraud.

Fraud is defined comparatively in article 313-1 of the Penal Code of France; in s 178BA of the Crimes Act of New South Wales; in s 82 of the Crimes Act of Victoria; and in s 408C of the Queensland Criminal Code. Each of these provisions makes it an offence to obtain money, property, services, a benefit, or an advantage, dishonestly or by deceit. The offences are punishable by 
imprisonment for 5 to 10 years, and a $€ 375,000$ fine under the French provision.

A professional athlete's ability to compete and earn a living in the sports industry is based on his or her physical or athletic ability. Enhancing that ability through the use of drugs may be regarded as a dishonest act. The drugged athlete falsely portrays his competence in securing a place to compete in a sporting event. The very nature of sports competition means that one athlete is chosen ahead of thousands of others, even before a major race is run. If an athlete obtains a position in a team, or in a race, ahead of thousands of others, or maintains his place as an elite athlete, whilst using drugs, he has deprived another, more deserving athlete, who is clean, from their rightful place. Fellow athletes, sponsors, race organizers and the public are deceived by such conduct.

Arguably, a drug-taking athlete who is on a scholarship paid for by the taxpayers of Australia, is potentially liable to a charge of fraud under the criminal code. ${ }^{2}$ Is the using of a banned substance that enhances athletic performance, thereby obtaining and retaining a monetary scholarship, deceptive conduct? Isn't such an athlete dishonestly benefiting himself in obtaining the scholarship, as well as dishonestly causing a detriment to all the other athletes who don't take drugs and who might have received the scholarship instead?

The outcome of such cases may be very different if expert police investigative techniques had been employed instead of an administrative enquiry. Had proceedings been instituted by a formal police investigation, in which the scene of the offending behaviour was treated as a crime scene and evidence been taken in accordance with correct police procedure, not only administrative procedures but also criminal justice may have been pursued successfully. Formal searches and seizures of doping paraphernalia in France and in Italy result in formal charges and trials against cyclists.

2 For example, an athlete on a scholarship from the AIS could be liable for prosecution under, eg, the South Australian Criminal Law Consolidation Act 1935:

Section 139-Deception

A person who deceives another and, by doing so -

(a) dishonestly benefits him/herself or a third person; or

(b) dishonestly causes a detriment to the person subjected to the deception or a third person, is guilty of an offence.

Maximum penalty:

(a) for a basic offence-imprisonment for 10 years;

(b) for an aggravated offence-imprisonment for 15 years. 


\section{The use of criminal justice mechanisms in sport}

Prosecuting cheating riders and sports managers under a charge of fraud may create an environment which requires them to think twice before injecting performance-enhancing drugs. The present system of sports suspensions, innuendo, scandals, and press reports fails to quell the continued use of drugs in cycling. The practice of doping in cycling goes on, yet with more guile. Top riders are still prepared to risk using drugs. They do so because the repercussions for using drugs in sport are not dire. Others, such as Belgian champion Tom Boonen, a self-confessed clean athlete, are left by the side of the road in the 2006 Tour de France weeping.

Adopting criminal justice mechanisms and being firm in denunciation of dishonest conduct in sport through the use of criminal charges against athletes and sports managers will challenge the culture of greed more directly than is achievable through administrative sanction and education. When doping in sport is regarded not only as a breach of the rules of sport, but also as an offence against the public generally, we may regain faith in sportsmanship. 